\title{
Analysis of congestion cost at signalized intersection using Vissim 9 (Case study at Demak Ijo Intersection, Sleman)
}

\author{
Noor Mahmudah ${ }^{1, *}$, Rizkie Akbar ${ }^{1}$, and Muchlisin ${ }^{1}$ \\ ${ }^{1}$ Muhammadiyah University of Yogyakarta, Depart of Civil Engineering, Jl. Brawijaya, Indonesia
}

\begin{abstract}
Due to imbalance of road capacity and traffic volume, so traffic congestion will be occurred either along the road and intersection. Demak Ijo intersection is one of signalized junction located in the western part of Yogyakarta with high traffic volume so traffic congestion is frequently occurred. The aim of this study is to analyze the performance of existing traffic condition and then estimate the congestion cost at signalized intersection by modeling (simulation) using Vissim 9 . The analysis results show that existing traffic condition is in very bad condition (level F), average delay of 80 seconds, average queue length of 48.73 meters with congestion cost is about Rp. 2,830,336 per hour.
\end{abstract}

\section{Introduction}

Congestion is one of significant transportation problems in many urban roads in Indonesia. Traffic congestion will be occurred either along the road and intersection due to imbalance the road capacity and traffic volume. In addition, mostly congestion will generate problems such as the reducing of vehicle speed that lead to the increasing of travel time, higher operating cost, and negative impact to the environment like air pollution produced by motorized vehicle.

The congestion will increase the transportation cost. As stated by Stubs in Sugiyanto [1], the cost of congestion is a relationship between speed and flow on the road and the relationship of speed and vehicle operating cost. It means when the existing traffic flow is increased hence the average traffic speed will decrease. Since the speed of vehicle is slower so the travel time is longer and then lead to the higher vehicle operating costs.

In general, the transportation in Yogyakarta is mixed traffic and overloaded on some road segments. It is due to the average growth of private vehicle in Yogyakarta city is $4.04 \%$ per year [2]. Demak Ijo intersection is one of the signalized junction which is located in the western part of Yogyakarta with high traffic volume where traffic congestion is frequently occurred. Therefore, this study attempts to analyze the congestion cost as a result of the low traffic performance at signalized intersection.

\footnotetext{
* Corresponding author: noor.mahmudah@umy.ac.id.
} 


\section{Literature review}

Congestion is defined as the impedance vehicles impose on each other, due to the speedflow relationship, in conditions where the use of a transport system approaches its capacity [3]. Tzedakis [4] stated that the theory of congestion cost was not based on the concept of homogenous traffic and the relationship of speed and flow. The congestion cost is the quantification of delay cost and changes in vehicle operating cost caused by slow traffic. In addition, Nash in Basuki and Siswandi [5] highlighted that congestion cost is a travel expense due to traffic delay or additional vehicle volume approaching or exceeding road service capacity. Verhoef in Sugiyanto [2] defined the congestion cost as representation of the difference of marginal social cost (MSC) to marginal private cost (MPC). Some studies related to congestion cost have been conducted by Tzedakis [4], Basuki and Siswadi [5], and Sugiyanto $[3,6]$. Mostly studies focused on congestion cost that were occurred in road segment.

Theory of Tzedakis [4] highlighted the congestion cost resulted by slow traffic by time period (i.e. per hour) that can be estimated by considering the followings:

1) Slow vehicle (traffic) due to congestion will cause the delay of fast vehicle;

2) As a result the queuing time will be occured on the road segment or intersection;

3) The expected value of the sum queuing time of fast vehicle impeded by the slow one is then estimated;

4) Based on the expected value of the sum queuing time, the expected value of delay costs and the change in vehicle operating costs are then quantified;

5) These costs per hour are then estimated by multiplying the costs per slow vehicle journey by the hourly number of slow vehicle journeys;

6) The formula to calculate the congestion cost is as written on equation 1

where:

$$
C=N^{*}\left[G A+\left(1-\frac{\boldsymbol{A}}{\boldsymbol{B}}\right) V^{\prime}\right] T
$$

$C=$ Congestion Cost (Rupiah),

$N=$ Vehicle Volume (Vehicle),

$G=$ Vehicle Operating Cost (Rp/veh.km),

$A=$ Existing Speed (km/hour or kph),

$B=$ Ideal Speed (km/hour or $\mathrm{kph})$,

$V^{\prime} \quad=$ Vehicle Time Value (Rp/veh.hour)

$T=$ Delay Time (Hour).

The Vehicle Operating Cost (VOC) in Yogyakarta can be calculated using formula proposed by Sugiyanto [6] as written in equation 2 below.

$$
V o c=0.4937 v^{2}-60.218 v+29
$$

where

$\mathrm{V} \quad=$ vehicle speed $(\mathrm{Km} /$ Hour $)$

Vehicle Time Value is estimated by using Table provided by Indonesian Highway Capacity Manual (1995) as described on Table 1 below. 
Table 1. Vehicle time value

(Source: Indonesian Highway Capacity Manual, 1995)

\begin{tabular}{|l|r|r|}
\hline \multirow{2}{*}{ Type of Vehicle } & \multicolumn{2}{|c|}{ Vehicle Time Value (Rp/veh.hour) } \\
\cline { 2 - 3 } & Gross Domestic Product & Welfare maximation \\
\hline Motor Cycle & 315,00 & 736,00 \\
Passenger Car & $1.925,00$ & $3.281,00$ \\
Small Bus & $7.385,00$ & $12.572,00$ \\
Big Bus & $9.800,00$ & $18.211,00$ \\
Small Truck & $4.970,00$ & $5.605,00$ \\
Medium Truck & $4.970,00$ & $5.605,00$ \\
Big Truck & $4.970,00$ & 736,00 \\
\hline
\end{tabular}

\section{Methods}

The method applied in this study is as illustrated on Figure 1. Primary and secondary data collection have been conducted in order to obtain traffic data, cycle time (of traffic light), geometric data, road condition, vehicle speed, traffic volume, etc. These data are then utilized in traffic modeling/simulation by using software Vissim 9. The considerations are taken into account to the minimum congestion cost, queue length and delay, but the highest Level of Service (LOS).

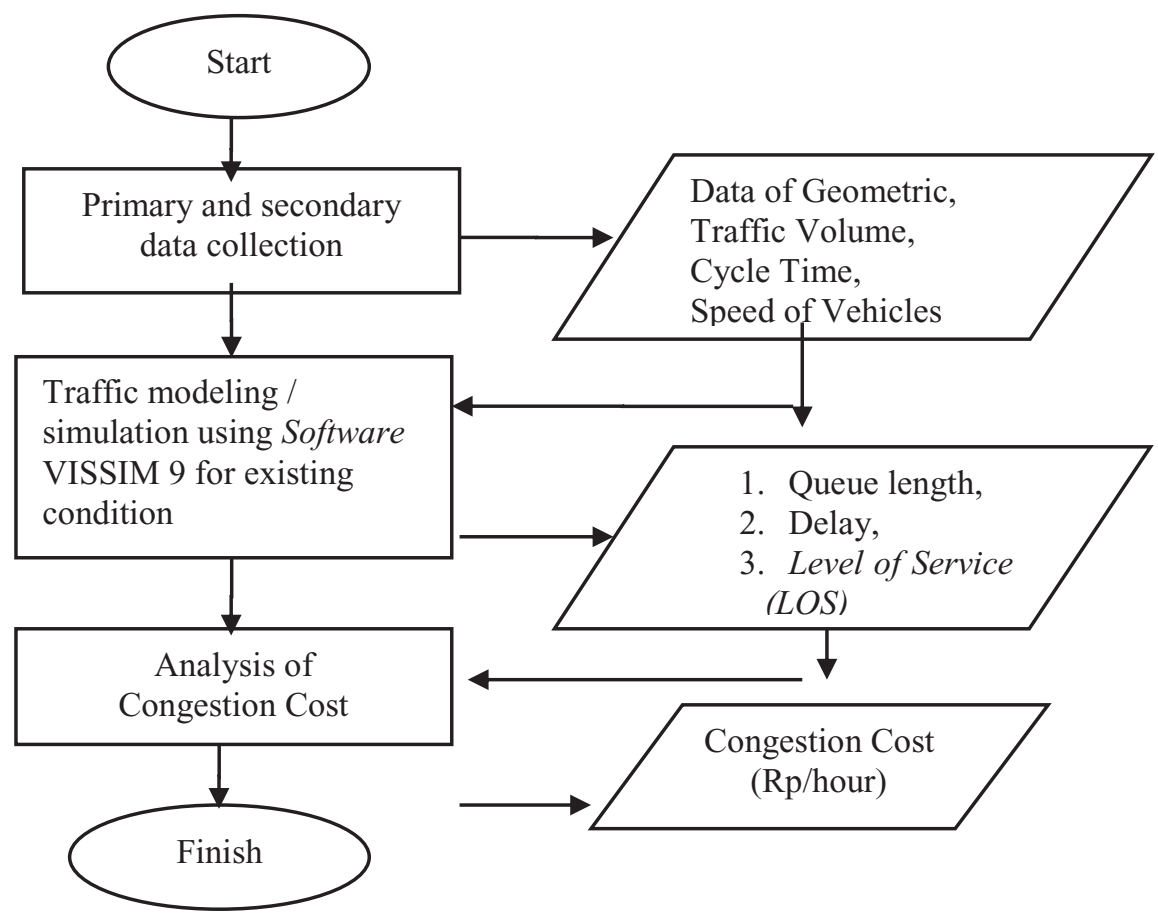

Figure 1. Research method

The study was conducted at signalized intersection of Demak Ijo, Godean Street, Sleman, Yogyakarta as shown in Figure 2 and 3. Traffic data utilizing in this study was collected by Umar [7], which was carried out for 12 hours on weekday at 06.00 up to 18.00 WIB. Moreover, in order to determine the geometric data at intersection, cycle time, road 
and environmental condition, the observation survey were also carried-out. The vehicle speed (spot speed) was conducted on three time: 06.00-08.00; 12.00-14.00, and 16.00-18.00 which represents the weekday traffic condition for every type of vehicle such as $\mathrm{HV}$ (Heavy Vehicle), LV (Light Vehicle), and MC (Motor Cycle).

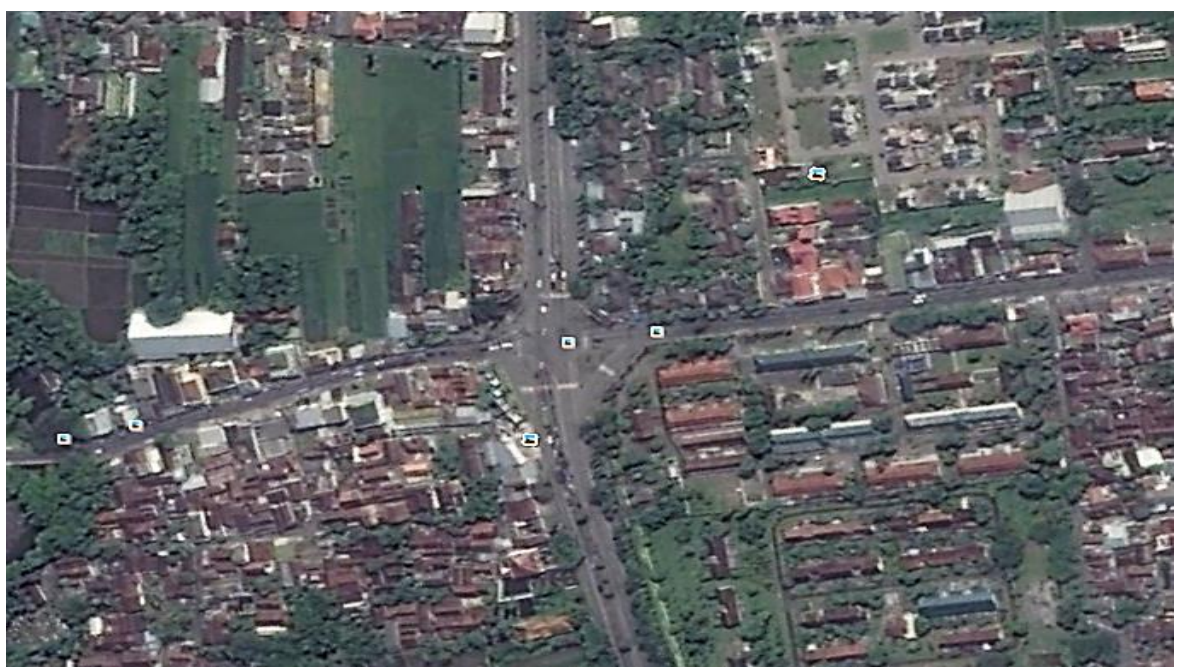

Figure 2. Demak Ijo intersection, Godean, Sleman

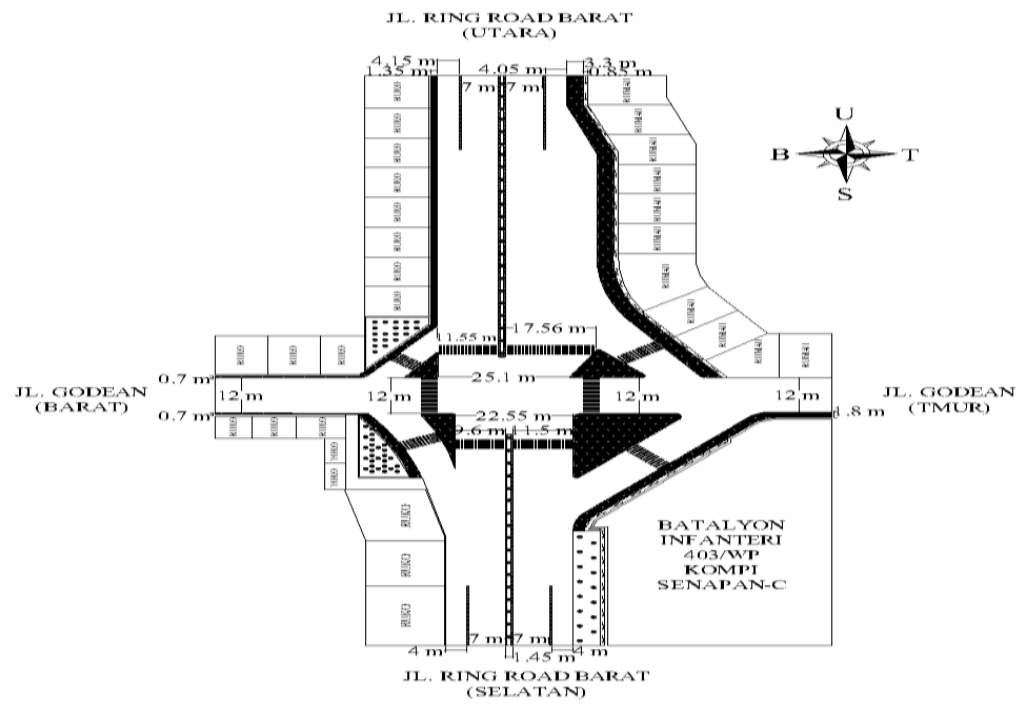

Figure 3. Geometric condition at Demak Ijo intersection, Godean, Sleman

\section{Analysis result and discussion}

\subsection{The existing phase condition}

The existing phase condition at Demak Ijo intersection can be seen in the Table 2 below. The total cycle time is 148 second for all arms. 
Table 2. Existing phase condition

\begin{tabular}{|c|c|c|c|c|c|c|}
\hline \multirow{2}{*}{ Signal } & \multirow{2}{*}{ Arm } & \multirow{2}{*}{ Type of Arm } & \multicolumn{4}{|c|}{ Time (second) } \\
\hline & & & Red & Green & Amber & All Red \\
\hline Phase 1 & $\mathrm{~N}$ & Protected $(\mathrm{P})$ & 138 & 35 & 3 & 4 \\
\hline Phase 2 & $\mathrm{E}$ & Protected $(\mathrm{P})$ & 148 & 25 & 3 & 4 \\
\hline Phase 3 & $\mathrm{~S}$ & Protected $(\mathrm{P})$ & 138 & 35 & 3 & 4 \\
\hline Phase 4 & W & Protected $(\mathrm{P})$ & 148 & 25 & 3 & 4 \\
\hline \multicolumn{3}{|c|}{ Cycle Time (second) } & \multicolumn{4}{|c|}{148} \\
\hline
\end{tabular}

\subsection{The traffic volume at peak hour}

The survey of traffic counting was conducted by Umar [7] in the period of 12 hours starting from 06.00 up to 18.00 . However, the data used for modelling the traffic at intersection is selected only during the peak hour (06.15.- 07.15). The traffic volume at peak hour obtained from the survey is as illustrated in Tabel 3.

Table 3 Data of traffic volume at peak hour [7]

\begin{tabular}{|c|c|c|c|c|c|c|c|}
\hline Time & \multicolumn{2}{|c|}{ Arm Junction } & $\mathrm{HV}$ & LV & $\mathrm{MC}$ & NMV & Total \\
\hline \multirow{16}{*}{$\begin{array}{c}6.15 \\
\text { s.d } \\
7.15 \\
\text { WIB }\end{array}$} & \multirow{3}{*}{$\begin{array}{l}\text { North } \\
\text { (A) }\end{array}$} & T. Left & 1 & 68 & 540 & 16 & 625 \\
\hline & & Straight & 26 & 332 & 1135 & 2 & 1495 \\
\hline & & T. Right & 5 & 118 & 452 & 0 & 575 \\
\hline & \multicolumn{2}{|c|}{ Total } & 32 & 518 & 2127 & 18 & 2695 \\
\hline & \multirow{3}{*}{ East (B) } & T. Left & 1 & 87 & 268 & 2 & 358 \\
\hline & & Straight & 6 & 91 & 749 & 7 & 853 \\
\hline & & T. Right & 2 & 50 & 482 & 19 & 553 \\
\hline & \multicolumn{2}{|c|}{ Total } & 9 & 228 & 1499 & 28 & 1764 \\
\hline & \multirow{3}{*}{$\begin{array}{l}\text { South } \\
\text { (C) }\end{array}$} & T. Left & 5 & 21 & 87 & 6 & 119 \\
\hline & & Straight & 28 & 689 & 3118 & 8 & 3843 \\
\hline & & T. Right & 5 & 67 & 434 & 2 & 529 \\
\hline & \multicolumn{2}{|c|}{ Total } & 38 & 777 & 3639 & 16 & 4491 \\
\hline & \multirow{3}{*}{$\begin{array}{l}\text { West } \\
\text { (D) }\end{array}$} & T. Left & 1 & 210 & 650 & 9 & 870 \\
\hline & & Straight & 6 & 169 & 3838 & 34 & 4047 \\
\hline & & T. Right & 0 & 62 & 703 & 1 & 766 \\
\hline & \multicolumn{2}{|c|}{ Total } & 7 & 441 & 5191 & 44 & 5683 \\
\hline
\end{tabular}

\subsection{Stages of traffic modeling by using Vissim 9}

In general, the stages of traffic modeling using software Vissim 9 as illustrated in Figure 4, which consist of input data, analysis, and obtain the output. 


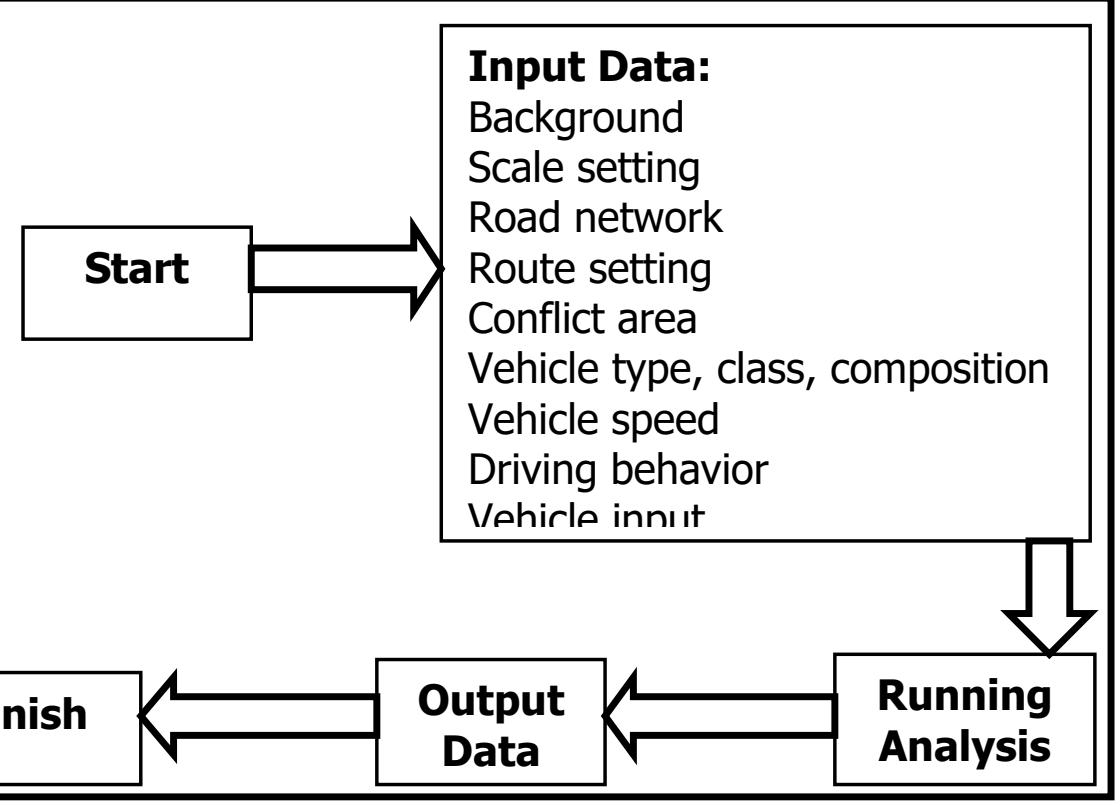

Figure 4. Stages of modeling using software Vissim 9

\subsection{Output data of Vissim 9}

The output resulted from simulation using software Vissim 9 is as shown in Table 4. It can be seen from the table that the maximum vehicle delay occured is 232 second and the longest queing is 214 meter at west arm with level of service F (very bad).

Table 4. The output data of Vissim 9 for existing condition

\begin{tabular}{|c|c|c|c|c|c|c|c|c|c|c|}
\hline $\begin{array}{l}\text { Time } \\
\text { Interval }\end{array}$ & Arm & Direction & $\begin{array}{l}\text { QLen } \\
\text { (m) }\end{array}$ & $\begin{array}{l}\text { QLen } \\
\text { Max } \\
\text { (m) }\end{array}$ & $\begin{array}{l}\text { Vehs } \\
\text { (AII) } \\
\text { (veh) }\end{array}$ & $\begin{array}{l}\text { LOS } \\
\text { (Ail) }\end{array}$ & $\begin{array}{l}\text { LOS Val } \\
\text { (All) }\end{array}$ & $\begin{array}{c}\text { Veh } \\
\text { Delay } \\
\text { (All) } \\
\text { (second) }\end{array}$ & $\begin{array}{c}\text { Stop } \\
\text { Delay } \\
\text { (All) } \\
\text { (second) }\end{array}$ & $\begin{array}{l}\text { Stops } \\
\text { (All) } \\
\text { (veh.) }\end{array}$ \\
\hline $0-3600$ & \multirow{3}{*}{ North } & $(\mathrm{N})-(\mathrm{E})$ & 01.24 & 20.51 & 96 & LOS_A & 1 & 08.36 & 0,088889 & 0,052083 \\
\hline $0-3600$ & & $(\mathrm{~N})-(\mathrm{S})$ & 103.21 .00 & 201.34.00 & 143 & LOS_F & 6 & 123.42 .00 & 106.14 .00 & 02.43 \\
\hline $0-3600$ & & $(\mathrm{~N})-(\mathrm{W})$ & 0,884722 & 67.07 .00 & 73 & LOS_E & 04.05 & 60.685 & 49.48 .00 & 01.02 \\
\hline $0-3600$ & \multirow{3}{*}{ East } & $(E)-(S)$ & 01.12 & 18.24 & 64 & LOS_A & 1 & 3.055 & 2.235 & 00.14 \\
\hline $0-3600$ & & $(\mathrm{E})-(\mathrm{W})$ & 72.49 .00 & 150.05 .00 & 86 & LOS_F & 6 & 110.25 .00 & 85.92 & 02.13 \\
\hline $0-3600$ & & $(\mathrm{E})-(\mathrm{N})$ & 1,014583 & 58.31 .00 & 62 & LOS_E & 04.05 & 58.975 & 52.845 & 0,065278 \\
\hline $0-3600$ & \multirow{3}{*}{ South } & $(\mathrm{S})-(\mathrm{W})$ & 00.38 & 13.03 & 39 & LOS_A & 3 & 37.31 .00 & 25.445 & 01.04 \\
\hline $0-3600$ & & $(\mathrm{~S})-(\mathrm{N})$ & 128.18 .00 & 186.33 .00 & 143 & LOS_F & 6 & 135.61 & 104.975 & 04.07 \\
\hline $0-3600$ & & $(\mathrm{~S})-(\mathrm{E})$ & 13.39 & 69.96 & 76 & LOS_D & 4 & 48.42 .00 & 37.26 .00 & 01.21 \\
\hline $0-3600$ & \multirow{3}{*}{ West } & $(\mathrm{W})-(\mathrm{N})$ & 0 & 12.07 & 145 & LOS_A & 1 & 1.195 & 00.52 & 00.18 \\
\hline $0-3600$ & & $(W)-(E)$ & 173.92 & 214.42 .00 & 87 & LOS_F & 6 & 232.63 & 196.73 & 0,224306 \\
\hline $0-3600$ & & $(\mathrm{~W})-(\mathrm{S})$ & 46.225 & 122.37 .00 & 87 & LOS_D & 5 & 139.07 .00 & 72.035 & 0,068056 \\
\hline $0-3600$ & \multicolumn{2}{|c|}{ Average } & 48.73 & 214.42 .00 & 1101 & LOS_F & 6 & 80 & 61.27 .00 & 0,088889 \\
\hline
\end{tabular}

\subsection{Vehicle operating cost (VOC)}

By employing equation 2 and considering the speed of vehicle, type of vehicle, and arm of intersection, so the vehicle operating cost (VOC) in existing condition at Demak Ijo 
intersection as shown in Table 5. The highest VOC is at west arm which is Rp. 1594/veh.km.

Table 5. Vehicle operational cost for existing condition

\begin{tabular}{|c|c|c|c|}
\hline \multirow{2}{*}{ No } & \multirow{2}{*}{ Arm } & \multirow{2}{*}{ Vehicle Type } & VOC \\
\hline & & & (Rp/Veh.km) \\
\hline \multirow{3}{*}{1} & \multirow{3}{*}{ NORTH } & $\mathrm{HV}$ & 1354 \\
\hline & & $\mathrm{LV}$ & 1221 \\
\hline & & MC & 353 \\
\hline \multirow{3}{*}{2} & \multirow{3}{*}{ EAST } & $\mathrm{HV}$ & 1478 \\
\hline & & LV & 1365 \\
\hline & & $\mathrm{MC}$ & 351 \\
\hline \multirow{3}{*}{3} & \multirow{3}{*}{ SOUTH } & $\mathrm{HV}$ & 1247 \\
\hline & & $\mathrm{LV}$ & 1158 \\
\hline & & $\mathrm{MC}$ & 378 \\
\hline \multirow{3}{*}{4} & \multirow{3}{*}{ WEST } & $\mathrm{HV}$ & 1582 \\
\hline & & LV & 1594 \\
\hline & & $\mathrm{MC}$ & 351 \\
\hline
\end{tabular}

\subsection{Travel time value (V)}

The time value is calculated using the study of Indonesian Highway Capacity Manual (1995) as illustrated in Table 1. Based on the vehicle type, the travel time value for Heavy Vehicle is estimated Rp. 4,970, Light Vehicle Rp. 1,925, and Motor Cycle Rp. 315.

\subsection{Congestion cost analysis}

The total congestion cost at Demak Ijo intersection in existing condition can be seen on Table 6 below. The total congestion cost at the junction is Rp. 2,830,336 per hour.

Table 6. Total Congestion Cost for Existing Condition at Demak Ijo Intersection

\section{Conclusions}

By considering the analysis results of simulation using software VISSIM 9 for signalized intersection of Demak Ijo, Godean, Sleman, Yogyakarta, it can be concluded as follows.

1. The traffic performance of existing condition of signalized intersection Demak Ijo, Godean, Sleman, Yogyakarta is very bad (level F) with the highest traffic volume (peak hour) occurs in the morning at 06.15 - 07.15 WIB with traffic volume 14,633 vehicle, average delay of 80 seconds, and average queue length of 48.73 meters.

2. The congestion costs at signalized intersection of Demak Ijo, Godean, Sleman, Yogyakarta, which is occurred at peak hour, is Rp. 2,830,336 per hour. 


\section{Acknowledgements}

My highly appreciations are addressed to my colleagues Muchlisin, M.Sc. and Dian Setiwan, M.Sc., Sc. and my student Muhammad Ade Alvianto Umar, who had been collaborating and contributing to this study in Civil Engineering Department, Universitas Muhammadiyah Yogyakarta.

\section{Referencers}

1. Sugiyanto, G, Biaya Kemacetan (Congestion Cost) Mobil Pribadi di Central Business District (2008)

2. Sugiyanto, G, et al, Pengembangan Model Biaya Kemacetan Bagi Pengguna Mobil Pribadi di Daerah Pusat Perkantoran Yogyakarta. Jurnal Transportasi 11, 2, 87-94 (2011)

3. Sugiyanto, G, et al, Modeling the Effect of Congestion Pricing on Mode Choice in Yogyakarta, Indonesia. International Journal of Engineering \& Technology IJET IJENS 11, 01. 85-94 (2011)

4. Tzedakis, A, Different Vehicles Speeds and Congestion Costs. Journal of Transport Economics and Policy XIV, 1, 81-103 (1980)

5. Basuki, Siswandi, Biaya Kemacetan Ruas Jalan Kota Yogyakarta. Jurnal Teknik Sipil 9, $1,71-80(2008)$

6. Sugiyanto, G, et al, Pemodelan Biaya Kemacetan Pengguna Mobil Pribadi Dengan Variasi Nilai Aktual Kecepatan Kendaraan. Jurnal Transportasi 12, 2, 123-132 (2012)

7. Umar, M.A.A, Analisis Kinerja Simpang Bersinyal pada Persimpangan Demak Ijo, (2016)

8. Directorate General of Highway, Ministry of Public Works the Republic of Indonesia (2010)

9. Khisty dan Lall, Dasar- Dasar Rekayasa Transportasi (2005)

10. Mahmudah. N, Bayunagoro. D.H, Pemodelan Lalu Lintas pada Simpang Bersinyal di Kota Yogyakarta (Studi Kasus Simpang Pingit). Proceedings of SNTT IV. UMP. Purwokerto. 26 November 2016. ISSN: 2339-028X (2016)

11. Ministry of Transportation Republic Indonesia, Peraturan Menteri No. 96 Tahun 2015. Tentang Pedoman Pelaksanaan Kegiatan Manajemen dan Rekayasa Lalu Lintas (2015)Munawar, A, Dasar-dasar Rekayasa Transportasi (2005)

12. Putranto, L.S, Rekayasa Lalu Lintas (Edisi 3) (2016)

13. PTV VISSION, PTV VISSIM 9 User Manual. PTV AG (2016)

14. The Goverment of Republic Indonesia, Undang - Undang Republik Indonesia No 22 Tahun 2009 Tentang Lalu Lintas dan Angkutan Jalan (2009) 